\title{
Postoperative abnormalities of the choriocapillaris in exudative age-related macular degeneration
}

\author{
John S Pollack, Lucian V Del Priore, Morton E Smith, Michael A Feiner, Henry J Kaplan
}

\begin{abstract}
Aims-To study the incidence and possible cause of abnormalities of the subfoveal choriocapillaris after surgical excision of subfoveal choroidal neovascularisation in age-related macular degeneration (ARMD).

Methods-The postoperative fluorescein angiograms and colour photographs of 29 eyes of 29 patients were reviewed after surgical excision of subfoveal choroidal neovascularisation in exudative ARMD. Preoperative and postoperative fluorescein angiograms were examined for perfusion of the subfoveal choriocapillaris. The excised subfoveal choroidal neovascular membranes from eight eyes that demonstrated postoperative abnormalities of the choriocapillaris were embedded in paraffin, serially sectioned and examined for the presence of the choriocapillaris.

Results-Postoperative fluorescein angiograms revealed abnormal perfusion of the subfoveal choriocapillaris in 26 of the 29 eyes $(90 \%)$ and in all eight eyes that had histopathological examination of the surgical specimens. Examination of serial sections demonstrated that none of the excised neovascular membranes contained choriocapillaris.

Conclusions-Abnormal perfusion of the subfoveal choriocapillaris was frequently present following removal of the subfoveal neovascular membrane in ARMD. The histopathological study demonstrated that abnormalities of the choriocapillaris were not due to removal of the choriocapillaris at the time of surgery.

(Br f Ophthalmol 1996; 80: 314-318)
\end{abstract}

Barnes Retina

Institute and the

Department of

Ophthalmology and

Visual Sciences,

Washington University

School of Medicine, St

Louis, Missouri, USA

J S Pollack

L V Del Priore

M E Smith

M A Feiner

H J Kaplan

Correspondence to: Dr H J Kaplan, Box 8096, Department of

Ophthalmology and Visual Sciences, Washington Medicine, 660 S Euclid Avenue, St Louis, MO 63110, USA.

Accepted for publication 30 November 1995
The introduction of subfoveal surgery for the treatment of exudative age-related macular degeneration (ARMD) and the presumed ocular histoplasmosis syndrome (POHS) has established the technical feasibility of removing subfoveal neovascular membranes. ${ }^{1-4}$ However, the excision of subfoveal membranes in ARMD has not been associated with the return of foveal vision except in occasional patients. $^{2-4}$ This is in contrast with the more favourable prognosis following similar surgery in patients with POHS. ${ }^{1-3}$ While the technique used to remove these membranes has been refined, these changes have not been accompanied by a significant improvement in visual outcome in exudative ARMD.

There are several possible explanations for the limited visual prognosis in ARMD patients following submacular surgery including: (1) pre-existing or iatrogenic damage to the photoreceptors; (2) pre-existing or iatrogenic disruption of Bruch's membrane; (3) disruption of the retinal pigment epithelium (RPE) by the disease process or during surgery, with inability of the adjacent RPE to repopulate the denuded area; and (4) the absence of normal choriocapillaris beneath the fovea.

In this study, we reviewed the postoperative fluorescein angiograms of 29 eyes of 29 patients who had previously undergone surgery for subfoveal choroidal neovascularisation in exudative ARMD to determine the incidence of postoperative abnormalities of the subfoveal choriocapillaris. We identified surgically excised tissue from a subset of eight of the eyes which demonstrated abnormalities of the subfoveal choriocapillaris after surgery. We studied this subset of eight eyes with histopathology, to determine whether postoperative abnormalities of the subfoveal choriocapillaris were the result of removal of the choriocapillaris with the neovascular membrane.

\section{Material and methods}

We reviewed the records of 29 eyes of 29 patients who underwent surgical excision of subfoveal choroidal neovascularisation for exudative ARMD at the Washington University School of Medicine during 1991 and 1992 , and had gradable postoperative fluorescein angiograms and colour photographs. Preoperative photographs and fluorescein angiograms were obtained up to 96 hours before surgery on all patients. Postoperatively, these tests were performed between 3 and 18 months after surgery. Only the most recent postoperative fluorescein angiograms and colour photographs were studied in patients who had more than one photographic study after surgery.

Patients were classified as demonstrating abnormal perfusion of the subfoveal choriocapillaris postoperatively if there was absence of a subfoveal ground glass appearance characteristic of choriocapillaris filling in the choroidal flush of the fluorescein angiogram. Fluorescein angiograms and colour and redfree photographs were examined to ensure that there was no blockage of subfoveal choroidal fluorescence.

Surgical specimens suitable for histopathology were available from eight of these 29 eyes. Only a limited number of specimens were available because the choroidal neovascular membrane was removed with the vitrector in many patients. Surgically excised membranes 
Figure 1 Case 1. (A) Preoperative: fibrotic subfoveal choroidal neovascular membrane with an associated serous neurosensory detachment (arrows). (B) Choroidal membrane blocks

fluorescence of the

underlying choriocapillaris during the arterial phase of the fluorescein angiogram (area outlined by arrows).

(C) Diffuse staining of the neovascular complex in the late arteriovenous phase.

(D) Six months

postoperative: there is absence of pigment in the area of the excised membrane. Large choroidal vessels are clearly seen (large arrows). (E) Six months after operation. There is filling of the large choroidal vessels (arrows) in the area of the excised neovascular membrane, but no normal filling of the choriocapillaris in this area. (F) Histopathology of the excised neovascular complex. Vascular channels are present in the

membrane (large arrow). $R P E$ lines one side of the excised specimen, and a thickened basement

membrane is present under these cells (arrows). There is no choriocapillaris in this specimen (haematoxylin and eosin).

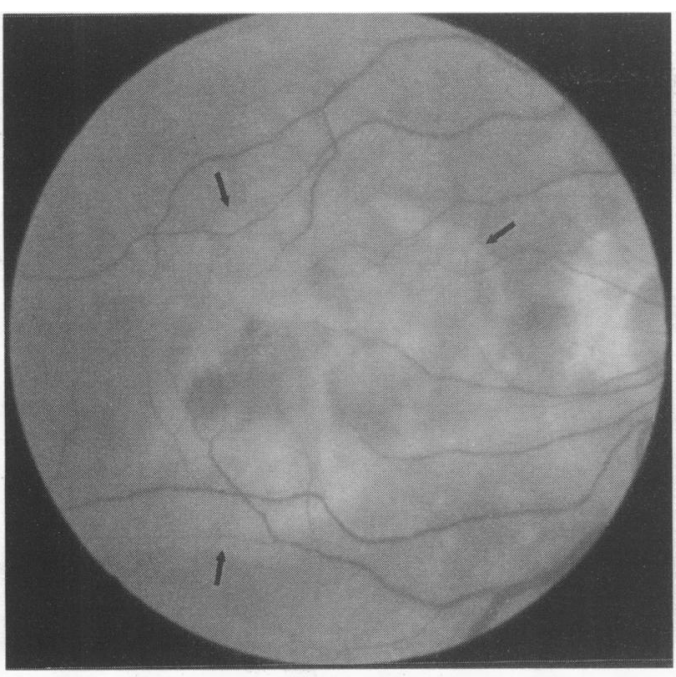

Fig $1 A$

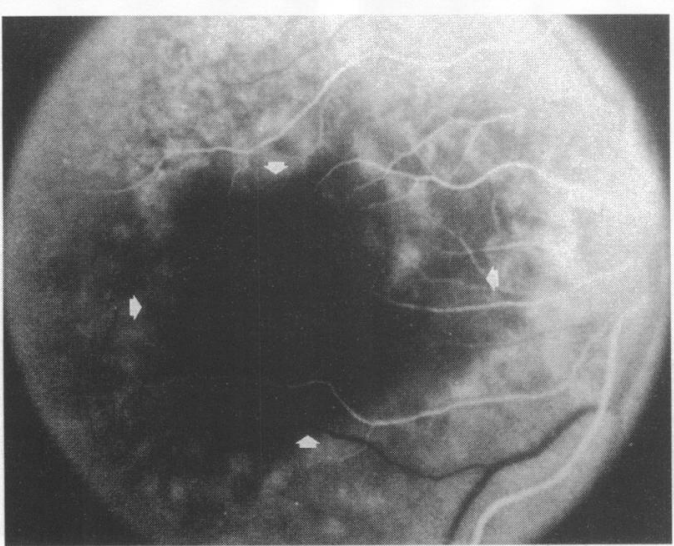

Fig $1 B$



Fig $1 D$

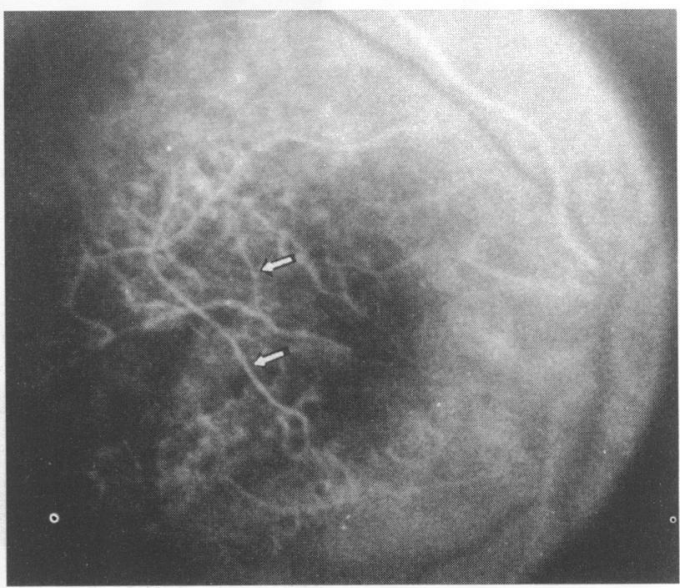

Fig 1E

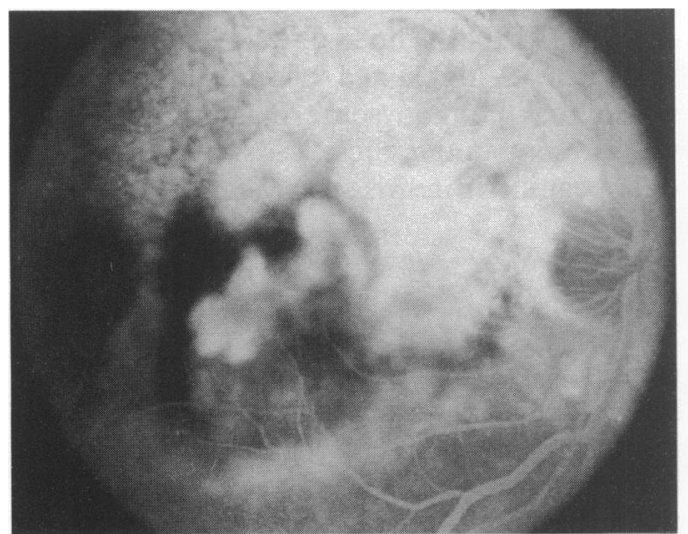

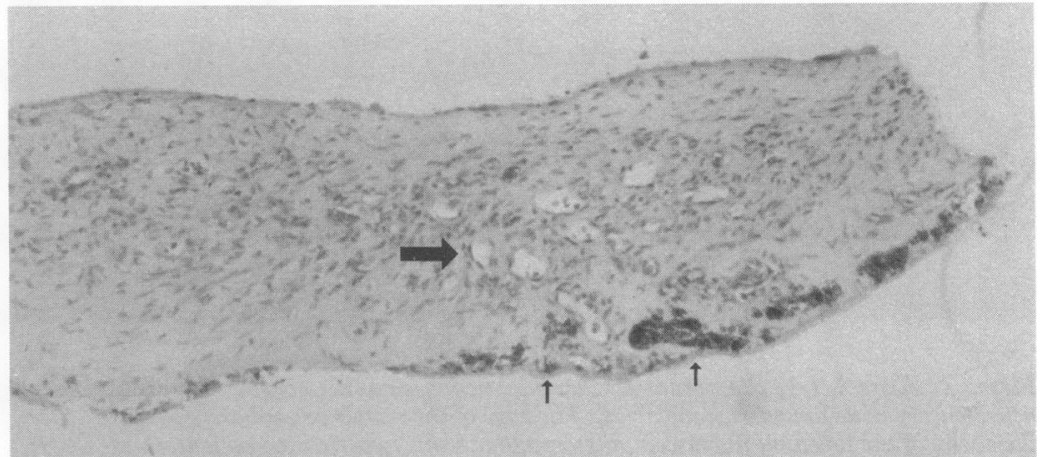

Fig $1 F$ were preserved in $10 \%$ formalin for at least 24 hours and processed for light microscopy. The specimens were washed in cacodylate buffer and dehydrated in a series of alcohol baths before immersion in xylene. Specimens were then infiltrated with paraffin and embedded in paraffin blocks. All eight specimens were serially sectioned (5-6 $\mu \mathrm{m}$ sections) and stained with haematoxylin and eosin. Serial sections were examined by light microscopy for the presence of choriocapillaris or capillary vessels in any of the excised membranes.

\section{Results}

Using the fluorescein angiographic criteria defined above, 26 of the 29 eyes $(90 \%)$ demonstrated abnormal perfusion of the subfoveal choriocapillaris postoperatively on fluorescein angiography.

Histopathological examination of serial sections of the surgical specimens did not demonstrate the presence of choriocapillaris in any of the eight specimens examined. Capillary vessels were only identified within the neovascular complex. ${ }^{5}$ The following examples illustrate the clinical and histopathological features exhibited by all eight of these cases.

CASE 1

A 73-year-old woman underwent surgical excision of a subfoveal neovascular membrane from ARMD in the right eye (Figs $1 \mathrm{~A}-\mathrm{C}$ ). 


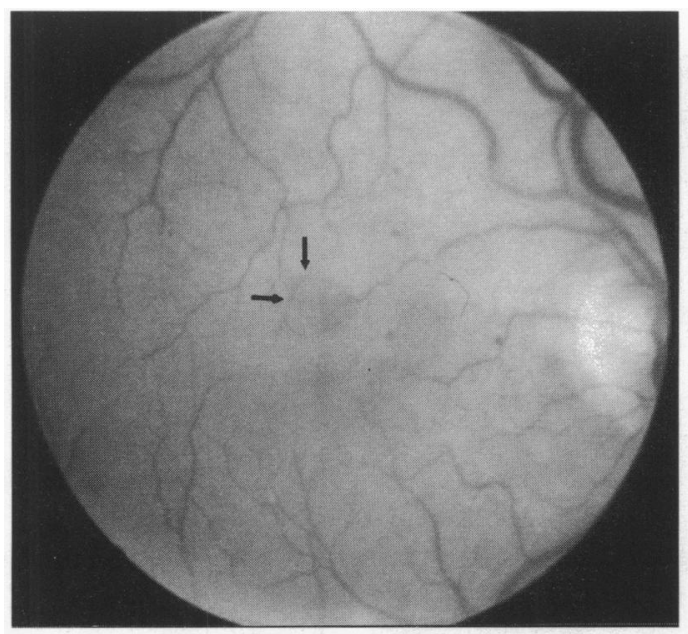

Fig $2 A$

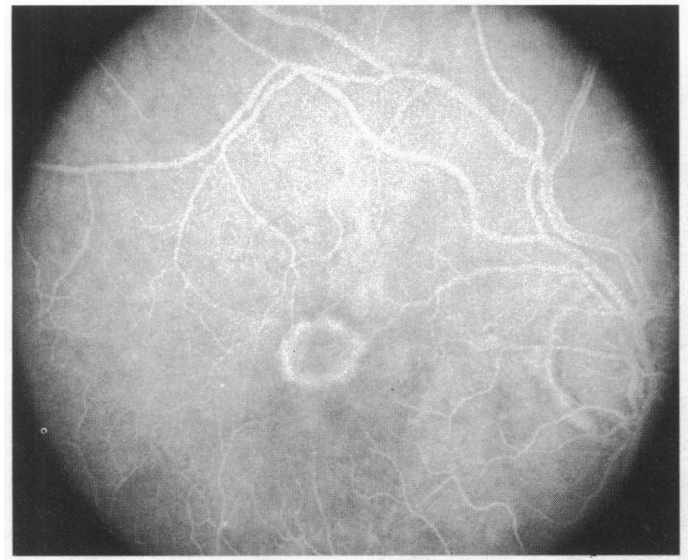

Fig 2B

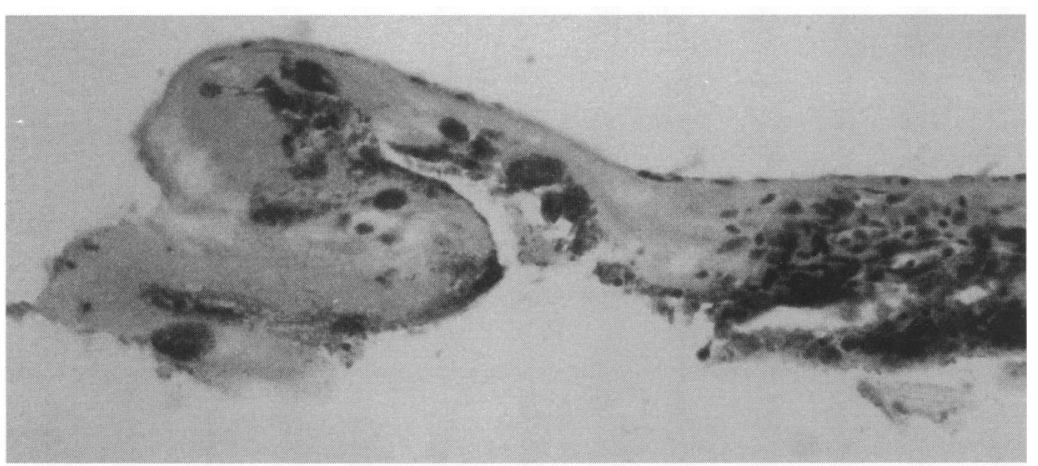

Fig 2E

Figure 2 Case 2. (A) Preoperative. Choroidal neovascular membrane with an associated neurosensory detachment (arrows). (B) The edge of the membrane is barely beneath the centre of the fovea on fluorescein angiography in this hypertensive patient.

(C) Postoperative appearance of the fundus at 1 month. An area of hypopigmentation is present. Persistent subretinal blood present nasal to the fovea is not uncommon 4 weeks after surgery. (D) Fluorescein angiography reveals filling of the large choroidal vessels (arrows) without normal filling of the associated choriocapillaris in the centre of the macula. (E) Histopathology of the excised neovascular membrane reveals an avascular fibrocellular stroma without evidence of excised choriocapillaris. Only a portion of the membrane is shown in the photograph, but the membrane appearance is uniform throughout the specimen (haematoxylin and eosin).

Perfusion of the underlying choriocapillaris could not be determined preoperatively because of blockage of fluorescence by the overlying membrane (Fig 1B). Six months postoperatively an area of hypopigmentation was present in the area of the excised neovascular complex (Fig 1D). Fluorescein angiography revealed filling of the large choroidal vessels without visible filling of the associated choriocapillaris (Fig 1E). Histopathology of the excised neovascular complex revealed small vascular channels only in the thickest

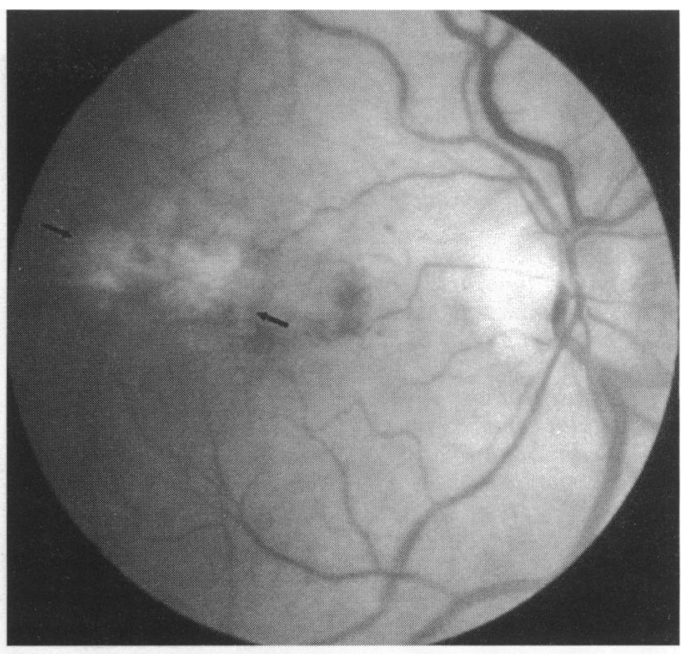

Fig $2 C$

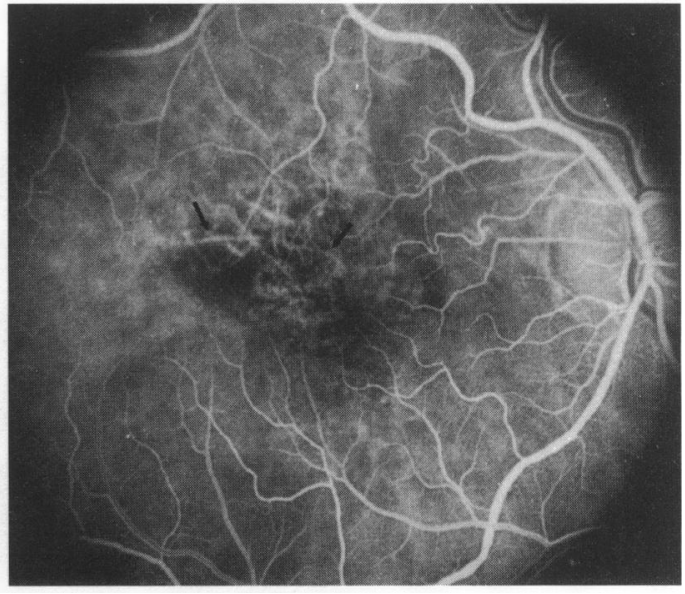

Fig $2 D$

portion of the membrane (Fig 1F, large arrow). A row of RPE cells lined one side of the excised specimen. A thickened basement membrane which may contain some Bruch's membrane was present under these cells. There was no choriocapillaris in this specimen.

CASE 2

An 82-year-old woman underwent surgical excision of a subfoveal choroidal neovascular membrane from the right eye (Fig 2A). Perfusion of the choriocapillaris under the membrane could not be determined preoperatively because of blockage by the overlying neovascular complex (Fig 2B). One month postoperatively, an area of hypopigmentation was present under the centre of the excised choroidal neovascular membrane (Fig 2C). Fluorescein angiography revealed filling of the larger choroidal vessels in the early $\mathrm{A}-\mathrm{V}$ phase, but there was no visible filling of the choriocapillaris under the centre of the fovea (Fig 2D). A line of pigmented RPE lined one side of the excised membrane, but there was no evidence of excised choriocapillaris (Fig 2E).

\section{Discussion}

Advances in pars plana vitrectomy techniques have made it technically feasible to remove subfoveal choroidal neovascular membranes in patients with ARMD, POHS, and other miscellaneous disorders. ${ }^{1-4}$ In POHS, up to $40 \%$ of 
patients experience an improvement of two lines or more in visual acuity after surgery ${ }^{1-3 a}$; however, similar improvement in visual acuity is uncommon in patients with ARMD. ${ }^{2-4}$ Many factors may account for the limited visual prognosis in ARMD patients following submacular surgery, including pre-existing or postoperative damage to the outer retina, RPE, Bruch's membrane, or choriocapillaris.

In this study, 26 of 29 eyes (90\%) demonstrated abnormalities of the subfoveal choriocapillaris on fluorescein angiography performed after surgery for subfoveal choroidal neovascularisation in ARMD. All patients had preoperative fluorescein angiography, but it was not possible to evaluate the subfoveal choriocapillaris preoperatively because the choroidal neovascular complex blocked fluorescence from the underlying choriocapillaris in these eyes. Postoperative fluorescein angiography revealed filling of the large choroidal vessels in the early phase without visible filling of the overlying choriocapillaris. This fluorescein angiographic finding is consistent with an abnormality of the choriocapillaris beneath the excised choroidal neovascular membrane. We cannot definitively conclude that the subfoveal choriocapillaris is absent on the basis of fluorescein angiography. We cannot exclude the possibility that the choriocapillaris is present but does not leak fluorescein, similar to its behaviour during indocyanine green angiography. However, it is clear that the behaviour of the choriocapillaris on fluorescein angiography is markedly abnormal after subfoveal surgery in these eyes.

Histopathological examination of serial sections of eight membranes demonstrated that the choriocapillaris was not present in any of the neovascular complexes examined histologically from patients with ARMD. The question arises as to whether or not it is possible to identify the choriocapillaris if it is removed with the subfoveal choroidal neovascular membrane. We have previously identified choriocapillaris in histological sections of a choroidal neovascular membrane in a patient with angioid streaks (unpublished observation). Thus, absence of the choriocapillaris on histopathology in this study suggests the choriocapillaris was not removed at the time of surgery. There are two possible explanations for these observations: (1) the choriocapillaris was not perfused preoperatively, implying that abnormal perfusion of this vascular structure was part of the primary disease process ${ }^{6-8}$; or (2) the choriocapillaris was normal preoperatively but became abnormal after surgery. ${ }^{9}$

Regardless of whether it occurred preoperatively or postoperatively, it is likely that changes in the choriocapillaris occurred secondary to dysfunction of the RPE. Henkind and Gartner have identified RPE loss to be a cause of choriocapillaris degeneration in retinitis pigmentosa, ${ }^{10}$ and Miller and colleagues noted similar findings in an experimental model of thioridizine retinopathy. ${ }^{11}$ Korte et al used sodium iodate to selectively destroy the RPE in rabbits. ${ }^{12}$ Degenerative changes in the RPE and choriocapillaris were observed 1 week after iodate injection. One month later patches of
Bruch's membrane became devoid of RPE and the choriocapillaris in these regions was found to be markedly atrophic. In contrast, the choriocapillaris had a normal appearance in areas where the RPE still appeared healthy.

We have previously developed a model to study the effects of RPE debridement on the morphology of the overlying retina and underlying choriocapillaris in the domestic pig and nonhuman primate. ${ }^{13} 14$ Previously debrided areas of Bruch's membrane were covered by a layer of hypopigmented RPE in most areas 1 month after RPE debridement, and the choriocapillaris, inner retina, and outer nuclear layer were ultimately intact in areas containing RPE. ${ }^{13} 14$ Some areas of Bruch's membrane remained devoid of RPE 4 weeks after surgery, and there was atrophy of the choriocapillaris, outer segments, and outer nuclear layer in these areas. ${ }^{13}$ These results suggest that absence of RPE leads to atrophy of the underlying choriocapillaris and overlying outer nuclear layer. The RPE may release a diffusible 'vascular modulating factor' which is necessary to preserve the morphology and function of the choriocapillaris. ${ }^{12}$ Recently, Yang and colleagues ${ }^{15}$ isolated a soluble angiogenic factor from human RPE which may be the postulated 'vascular modulating factor'.

Although initial attempts at RPE transplantation in ARMD have not been successful, ${ }^{16} 17$ the question remains open as to whether RPE transplantation will become an adjunct to submacular surgery in ARMD. If abnormalities develop in the choriocapillaris postoperatively, replacement of dysfunctional RPE with healthy RPE at the time of surgery might prevent postoperative changes in the subfoveal choriocapillaris. The pathological changes occurring in Bruch's membrane in ARMD ${ }^{18}$ will probably not be reversed by replacing dysfunctional, senescent RPE by healthy RPE, but reversal of Bruch's membrane changes may not be necessary for visual recovery.

Presented as a poster at the American Academy of Ophthalmology Annual Meeting, Chicago, November 1993. Supported in part by an unrestricted grant from Research to Prevent Blindness, Inc, New York, NY, the Kemper Fund, and core grant EY02687 from the National Eye Institute.

1 Thomas MA, Kaplan HJ. Surgical removal of subfoveal neovascularization in the presumed ocular histoplasmosis syndrome. Am $\mathcal{f}$ Ophthalmol 1991; 111: 1-7.

2 Berger AS, Kaplan HJ. Clinical experience with the surgical removal of subfoveal neovascular membranes. Ophthalmology 1992; 99: 969-76.

3 Thomas MA, Grand MG, Williams DF, Lee CM, Pesin SR, Lowe MA, et al. Surgical management of subfoveal choroidal neovascularization. Ophthalmology 1992; 99: 952-68.

3a Adelberg DA, Del Priore LV, Kaplan HJ. Surgical excision of idiopathic and miscellaneous choroidal neovascular membranes. Retina 1995; 15: 198-205.

4 Lambert HM, Capone A Jr, Aaberg TM, Sternberg P Jr, Mandell BA, Lopez PF. Surgical excision of subfoveal neovascular membranes in age-related macular degeneraneovascular membranes in age-related macula
tion. Am $\mathcal{F}$ Ophthalmol 1992; 113: 257-62.

5 Reddy VM, Zamora RL, Kaplan HJ. Distribution of growth factors in subfoveal neovascular membranes in age-related macular degeneration and presumed ocular histoplasmosis syndrome. Am $₹$ Ophthalmol 1995; 120: 291-301.

6 Sarks SH, Van Driel D, Maxwell L, Killingsworth M. Softening of drusen and subfoveal neovascularization. Trans Ophthalmol Soc UK 1980; 100: 414-22.

7 Green WR, Key SN III. Senile macular degeneration: a histopathologic study. Trans Am Ophthalmol Soc 1977; 75: 180-254.

8 Friedman E, Smith TR, Kuwabara T. Senile choroidal vascular patterns and drusen. Arch Ophthalmol 1963; 69: $220-30$

9 Nasir M, Zarbin MA. Choriocapillaris atrophy as a complibranes. Invest Ophthalmol Vis Sci 1993; 34 (suppl): 834. 
10 Henkind P, Gartner S. The relationship between retinal pigment epithelium and the choriocapillaris. Trans Ophthalmol Soc UK 1983; 103: 444-7.

11 Miller FS III, Bunt-Milam AH, Kalina RE. Clinical ultrastructural study of thioridazine retinopathy. Ophthalmology 1980; 89: 1478-88.

12 Korte GE, Reppucci V, Henkind P. RPE destruction causes choriocapillaris atrophy. Invest Ophthalmol Vis Sci 1984 25: 1135-45.

13 Del Priore LV, Kaplan HJ, Silverman MS, Hornbeck R, Jones Z, Swinn M. Debridement of the pig retinal pigment epithelium in vivo. Arch Ophthalmol 1995; 113: 939-44.

14 Valentino TL, Kaplan HJ, Del Priore LV, Fang SR, Berger A, Silverman MS. Retinal pigment epithelial repopulation in monkeys after submacular surgery. Arch Ophthalmol 1995; 113: 932-8.
15 Yang QR, Smets RME, Neetens A, Berghe DV. Human retinal pigment epithelial cells from different donors continuously produce a vascular endothelial cell-stimulating factor into serum-free medium. $₹$ Cell Sci 1993; 104: factor

16 Peyman GA, Blinder KJ, Paris CL, Alturki W, Nelson NC Jr, Desai U. A technique for retinal pigment epithelium transplantation for age-related macular degeneration secondary to extensive subfoveal scarring. Ophthalmic Surg 1991; 22: 102-8.

17 Algvere PV, Berglin L, Gouras P, Sheng Y. Transplantation of fetal retinal pigment epithelium in age-related macular degeneration with subfoveal neovascularization. Graefes Arch Clin Exp Ophthalmol 1994; 232: $707-16$.

18 Bird AC. Bruch's membrane changes with age. $\mathrm{Br} f$ Ophthalmol 1992; 76: 166-8.

\section{History of ophthalmology}

\section{Do you have a Roman connection?}

The Romans occupied Britain from $\mathrm{AD} 43$ to around $\mathrm{AD} 410$. Ophthalmic care was available from itinerant oculists who usually prescribed eye salves (collyria) or drops which were made from a block that was diluted with a fluid such as egg. The solid blocks were often stamped with details of the medicament and the name of the oculist. Some 300 stamps have been found in the Roman empire with 30 of these in Britain (see table). ${ }^{1}$ There are 20 modern day eye departments near to where finds have been made. Probably the most closely located is Moorfields Eye Hospital. A cup with an oculist's inscription by Lucius Iulius Senex for a saffron eye salve was found at nearby Moorgate Street in 1929. Single finds have been made in Wales, Scotland, and southern Ireland. Four of the stamps have been unearthed over the past 25 years. Perhaps there is one lying undiscovered near your hospital.

Department of Ophthalmology, Salisbury

HUGH F THOMAS

1 Collingwood RG, Wright RP. The Roman Inscriptions of Britain. Volume II. Stroud: Alan Sutton Publishers, 1992: 43-62.

Roman oculists' stamps found in Great Britain

\begin{tabular}{|c|c|c|c|}
\hline $\begin{array}{l}\text { Location of find } \\
\text { (Roman name) }\end{array}$ & $\begin{array}{l}\text { Year of } \\
\text { find }\end{array}$ & Named ingredients & Oculist's name \\
\hline $\begin{array}{l}\text { Bath } \\
\text { (Aquae Sulis) } \\
\text { Bedford }\end{array}$ & $\begin{array}{l}1731 \\
1923\end{array}$ & Vinegar, quince & $\begin{array}{l}\text { T Iunianus } \\
\text { Flavius Litugenus }\end{array}$ \\
\hline $\begin{array}{l}\text { (Biggleswade) } \\
\text { (Harrold) } \\
\text { Cambridge } \\
\text { (Duroliponte) }\end{array}$ & $\begin{array}{l}1873 \\
1895 \\
1984\end{array}$ & $\begin{array}{l}\text { Vinegar, celandine, poppy } \\
\text { Copper oxide, misy }\end{array}$ & $\begin{array}{l}\text { Gaius Valerius Amandus } \\
\text { Gaius Iunius Tertullus } \\
\text { Lucius Iulius Salutaris } \\
\text { Marinus }\end{array}$ \\
\hline $\begin{array}{l}\text { Chester } \\
\text { (Deva) }\end{array}$ & 1973 & Saffron & Quintus Iulius Martinus \\
\hline $\begin{array}{l}\text { Cirencester } \\
\text { (Corinium) } \\
\text { Colchester } \\
\text { (Camulodunum) } \\
\text { Dorchester } \\
\text { (Durnovaria) }\end{array}$ & $\begin{array}{l}1808 \\
1900 \\
1719 \\
1975 \\
1937\end{array}$ & $\begin{array}{l}\text { Frankincense, quince } \\
\text { Frankincense, quince, poppy } \\
\text { Saffron, quince } \\
\text { Saffron } \\
\text { Saffron }\end{array}$ & $\begin{array}{l}\text { Minervalis } \\
\text { Atticus } \\
\text { Quintus Iulius Murranus } \\
\text { Martialis }\end{array}$ \\
\hline $\begin{array}{l}\text { Edinburgh } \\
\text { (Tranent) }\end{array}$ & 1846 & Saffron & Lucius Valerius Latinus \\
\hline $\begin{array}{l}\text { Gloucester } \\
\text { (Lydney Park) } \\
\text { Hereford }\end{array}$ & c 1830 & Quince & Iulius Iucundus \\
\hline $\begin{array}{l}\text { (Kenchester) } \\
\text { (Magnis) } \\
\text { Ipswich } \\
\text { (Whitton) }\end{array}$ & $\begin{array}{l}1842 \\
1963 \\
1931\end{array}$ & $\begin{array}{l}\text { Nard, frankincense } \\
\text { Copper oxide, gall }\end{array}$ & $\begin{array}{l}\text { Titus Vindacius Ariovistus } \\
\text { Aurelius Polychronius }\end{array}$ \\
\hline $\begin{array}{l}\text { Kendal } \\
\text { (Watercrook) }\end{array}$ & 1974 & & Publius Clodius \\
\hline $\begin{array}{l}\text { Lincoln } \\
\text { (Littleborough) }\end{array}$ & 1772 & & \\
\hline $\begin{array}{l}\text { London } \\
\text { (Londinium) }\end{array}$ & $\begin{array}{l}1854 \\
1929 \\
1931\end{array}$ & $\begin{array}{l}\text { Saffron } \\
\text { Saffron } \\
\text { Misy }\end{array}$ & $\begin{array}{l}\text { Lucius Iulius Senex } \\
\text { Lucius Iulius Senex } \\
\text { Gaius Silvius Tetricus }\end{array}$ \\
\hline $\begin{array}{l}\text { Newport } \\
\text { (Caerleon; Isca) }\end{array}$ & 1955 & Saffron & Lucius Iulius Senex \\
\hline $\begin{array}{l}\text { Norwich } \\
\text { (Caistor St Edmunds) } \\
\text { (Venta Icenorum) }\end{array}$ & 1927 & & Publius Anicius Sedatus \\
\hline $\begin{array}{l}\text { Oxford } \\
\text { (Wilcote) }\end{array}$ & 1965 & & Maurus \\
\hline $\begin{array}{l}\text { Shrewsbury } \\
\text { (Wroxeter) } \\
\text { (Viroconium) }\end{array}$ & $\begin{array}{l}1808 \\
1981\end{array}$ & Frankincense & Tiberius Claudius $\mathbf{M}$ \\
\hline $\begin{array}{l}\text { St Albans } \\
\text { (Verulamium) }\end{array}$ & 1739 & Balsam, myrrh & $\begin{array}{l}\text { Lucius Iulius Iuvenis } \\
\text { Flavius Secundus }\end{array}$ \\
\hline Waterford & 1842 & Misy & Marcus Iuventius Tutianus \\
\hline York & 1930 & Misy & Iulius Alexander \\
\hline
\end{tabular}

*Probably copper pyrites. 